\title{
Teaching internship from the metaphorical lens of Filipino prospective teachers
}

\author{
Danilo V. Rogayan Jr. ${ }^{1}$, Denn Harry R. Reusia ${ }^{2}$ \\ ${ }^{1,2}$ College of Teacher Education, President Ramon Magsaysay State University-San Marcelino, Philippines \\ ${ }^{1}$ College of Graduate Studies \& Teacher Education Research, Philippine Normal University-Manila, Philippines
}

\begin{abstract}
Article Info
Article history:

Received Nov 26, 2020

Revised Jun 6, 2021

Accepted Jul 10, 2021

Keywords:

Metaphoric images

Philippines

Prospective teachers

Qualitative research

Teaching internship

ABSTRACT

Understanding prospective teachers' (PTs) conceptions and perspectives about teaching internship may serve as an anchor for understanding their new experiences. The study explores Filipino PTs' concepts of teaching internship through a metaphorical lens. Seventy-five PTs from a state-owned university in the Philippines served as the subjects of this qualitative inquiry. Data came from written narratives and explanations provided by the participants to describe their ideas on what a teaching internship is all about. The metaphoric images were enumerated, counted, interpreted, and classified to show meaningful patterns and themes. Findings showed that conceptions converged into six categories teaching internship as: 1) An endless learning venture; 2) A rewarding obstacle to surpass; 3) A chance to be a surrogate parent; 4) An enhancement of pedagogical competence; 5) An immersion in the actual workplace; and 6) An ultimate path towards becoming a teacher. Metaphors used by the participants were a mix of positive and negative symbolisms. The study offered possible descriptions for these conceptions and their implications on teacher education institutions (TEIs). The supervision of the off-campus teaching internship program could be enhanced at the onset of Education 4.0.
\end{abstract}

This is an open access article under the CC BY-SA license.

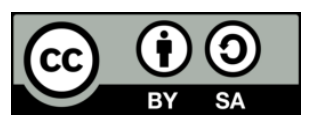

Corresponding Author:

Danilo V. Rogayan Jr.

College of Teacher Education

President Ramon Magsaysay State University

Nagbunga, San Marcelino, Zambales, 2207, Philippines

Email: danrogayan@prmsu.edu.ph

\section{INTRODUCTION}

Teaching internship is a vital phase in every teacher education program to prepare for becoming a full-fledged educator. In this stage, prospective teachers are trained with the rudiments of learning-centered instruction and immersed in the actual classroom experience to become equipped and qualified teachers in the country. To better understand the views of students on teaching internship, metaphors could be used. Metaphors are recognized for their critical input in recognizing, understanding and articulating experiences [1]. These have also been used as tools for research and even as instruments for teaching [2].

Studies on teaching internship have been extensively done around the world. Previous literature explored some aspects of practice teaching and teacher-teaching enhancement [3]-[13]. These researches have explicitly concentrated on actual teaching internship, from practicum experience to assessment, and its strengths and weaknesses.

Researches in teacher education in the Philippines, however, mainly focused on prospective teachers' (PTs) teaching views and drive [14], [15], beginning teachers' notion of pedagogical competence 
[16], teachers' conceptions of good and effective teaching [17], [18], and young teachers' whys and wherefores for teaching [19]. In terms of teaching internship, previous studies have focused mainly on the student experiences in their practicum [20], [21], the assessment of the pre-service teacher training and internship program [22]-[24], predicting internship success of prospective teachers [25], and the lived experiences of teacher interns during practice teaching [26].

Studies on exploring the conceptions and perspectives of prospective teachers regarding teaching internship have not been thoroughly carried out. Moreover, published researches which made use of metaphoric images specifically in the Philippine context is very limited. Carillo [27] conducted a study on Filipino PTs' preconceptions of teacher roles through a metaphorical perspective. Another study metaphorically analyzed students' perceptions of mathematical operations [28]. However, the present study focused its line of inquiry in exploring prospective teachers' conceptions regarding their off-campus teaching internship through a metaphorical perspective. Lakoff and Johnson [29] reiterated metaphors' significance in communicating phenomenological realities, accentuating how personal notions and views are generally framed based on their resemblances or differences. Propensities to operationalize concepts and to theorize about things consistent with existing metaphors have also been noted, emphasizing "how metaphors serve as blueprints of thinking" [30].

Thus, this qualitative inquiry intended to look into PTs' conceptions on teaching internship, framed through a metaphorical lens. An examination of prospective teachers' conceptions of teaching internship becomes a valuable endeavor when understood, considering that the current pre-service teachers are the future educators who will be part of the educational organizations [31]. Specifically, this study sought to: 1) Identify the metaphors used by teacher education students to describe teaching internship; 2) Categorize these metaphors based on essential themes and patterns; and 3) Formulate implications of these conceptions concerning a more relevant and responsive teaching internship program.

\section{RESEARCH METHOD}

\subsection{Research design}

This qualitative study explored the pre-service teachers' perspectives and conceptions through their written explanations and narratives using a metaphorical lens. Initiated by Lakoff and Johnson [29], metaphors are limited to the cognitive configuring of knowledge and experience.

\subsection{Research participants and setting}

The study purposively selected 77 teacher education students in a government-run teacher education institution in Central Luzon, Philippines. At the time of the study, all the participants have finished their teaching internship program in public schools regulated by the Philippine Department of Education (DepEd). The participants are in their last year of their teacher training programs under Bachelor of Secondary Education (BSEd) and Bachelor of Elementary Education (BEEd).

\subsection{Research tools and procedure}

The researchers met the participants in three groups. During the meeting, participants were given blank papers on where they completed the statement, "Teaching internship is like..." that represent their ideas on what a teaching internship is. They were asked to explain their responses. The sheets were then collected after everyone had finished writing. The encounter of the researchers with each group lasted for almost one and a half hours. The explanations written by the participants were encoded verbatim. No translation was done since the participants responded to the questions using the English language. The responses of the students were obtained in one-time data gathering and were not altered.

\subsection{Data analysis}

The researchers adopted the methodology employed by Carillo [27] in the analysis of the metaphoric illustrations. Metaphoric images culled from the pre-service students' responses were listed and counted according to the number of times the participants used them. The researchers checked the explanations that accompanied each of the responses. This is to understand "how the metaphors used by the participants were interpreted and hermeneutically chosen" [27] as an illustration of teaching internship. Concepts that were identified were reclassified into categories of similarly-interpreted illustrations [27]. Characteristics that underlie the concepts that form part of each category were analyzed to come up with relevant patterns and themes [27]. 


\section{RESULTS AND DISCUSSION}

The discussions of this inquiry's findings are presented in an exploratory manner and without any assertions that these can be generalized to other pre-service teachers of different circumstances. Further exploration of the resemblances and variances in the teaching internship images that accompany prospective teachers as they finish their teacher training programs needs to be carried out [31], [32]. There is a broad acknowledgement of these imageries' possible influence on the teacher's judgments, choices, whereabouts, and outlook [2].

\subsection{Teaching internship as an endless learning venture}

The first category of metaphoric images depicted teaching internship as a continuous learning experience as shown in Table 1. The participants conspired the process as a continuing development. They made use of the images of the zoo, being in the supermarket and the plant to illustrate the practicum as an avenue for exchange of knowledge. The knowledge-sharing in the current industrial era is very smooth, fastpaced and more convenient than before. The use of story and studying as images to describe teaching internship falls under the aspect of expanding the student interns' knowledge, skills, and values. The river, which is overflowing, was used by the participants to depict the transfer of learning from the teacher to the learners and vice-versa.

Table 1. Prospective teachers' conceptions of teaching internship as an endless learning venture

\begin{tabular}{|c|c|c|}
\hline Metaphoric representations & Associated meanings & Significant statements \\
\hline $\begin{array}{l}\text { Zoo, being in the } \\
\text { supermarket, plant }\end{array}$ & $\begin{array}{l}\text { Provides an avenue for } \\
\text { exchange of knowledge }\end{array}$ & $\begin{array}{l}\text { "I encountered different kinds of students to whom I also learn." } \\
\text { "Certainly, it's noisy, but there is an exchange of learning. I learn } \\
\text { from my cooperating teacher }(C T) \text {, from my students, and they also } \\
\text { learn from me." } \\
\text { "My CT helps me in everything that I need to prepare, especially my } \\
\text { lesson plans." }\end{array}$ \\
\hline Studying, story & $\begin{array}{l}\text { Broadens knowledge, } \\
\text { skills, and attitude }\end{array}$ & $\begin{array}{l}\text { "I learn a lot that enhances my knowledge, skills, and values to } \\
\text { become an efficient and effective educator and facilitator someday." } \\
\text { "Because in the end, it has a beautiful ending such as gaining } \\
\text { knowledge and experiences in how to deal with the different behaviors } \\
\text { of the learners." }\end{array}$ \\
\hline River & Transfers learning & $\begin{array}{l}\text { "Just like a river that is continuously flowing, a teacher continuously, } \\
\text { believes that learning must be provided for the sake of the learners, } \\
\text { future." }\end{array}$ \\
\hline
\end{tabular}

\subsection{Teaching internship as a rewarding obstacle to surpass}

The participants also cited teaching internship as a rewarding obstacle to surpass based from various metaphoric representations as shown in Table 2 such as exploring the vast ocean, unforgettable adventure, playing with waves, and mountain climbing to describe the challenges to overcome by the prospective teachers (PTs). The use of maze and soldier connotes that the internship allows the students to successfully use strategies and tactics to hurdle their internship. War, battle, experiencing life and death, swimming an 8-ft pool, Ferris wheel, sculpture making, swing and difficult task are symbolisms used by the participants. This is to describe that the internship program, though difficult and challenging, may provide silver lining or opportunities for learning. Notably, the prospective teachers used the pruning process, flower and messy world as representations of the way the practicum has changed their perspective from a negative to positive leanings. 
Table 2. Prospective teachers' conceptions of teaching internship as a rewarding obstacle to surpass

\begin{tabular}{|c|c|c|}
\hline $\begin{array}{c}\text { Metaphoric } \\
\text { representations }\end{array}$ & $\begin{array}{c}\text { Associated } \\
\text { meanings }\end{array}$ & Significant statements \\
\hline $\begin{array}{l}\text { Exploring vast ocean, } \\
\text { Unforgettable adventure, } \\
\text { Playing with waves, } \\
\text { Mountain climbing }\end{array}$ & $\begin{array}{l}\text { Poses challenges } \\
\text { to overcome }\end{array}$ & $\begin{array}{l}\text { "Beneath the ocean, there is a great diversity of species like the learners in a } \\
\text { public school. It is wide and full of challenges that you need to surpass before you } \\
\text { can see and appreciate the beauty in it." } \\
\text { "There are always be difficulties and challenges that you may encounter." } \\
\text { "I can't forget the many problems that I encountered." }\end{array}$ \\
\hline Maze, soldier & $\begin{array}{l}\text { Allows use of } \\
\text { strategies }\end{array}$ & $\begin{array}{l}\text { "I need to plan and organize, manage my time, and use available things so I can } \\
\text { use it as a tool to come out successfully." } \\
\text { "Without your weapons, you cannot win the battle." }\end{array}$ \\
\hline $\begin{array}{l}\text { War, Battle, experiencing } \\
\text { life and death, swimming } \\
\text { an 8-ft pool, Ferris wheel, } \\
\text { Sculpture making, Swing, } \\
\text { Difficult task }\end{array}$ & $\begin{array}{l}\text { Provides silver } \\
\text { lining }\end{array}$ & $\begin{array}{l}\text { "You need to battle out with different problems, sleepless nights. But when your } \\
\text { pupils learned from you, that's the time you would say, I have won this battle." } \\
\text { "Even it is happy, there would always challenging factors every time you'll teach. } \\
\text { I realize that this is how education works, and I felt satisfied because I love } \\
\text { teaching children." } \\
\text { "It has ups and downs while experiencing it, but it will end up fun and exciting." } \\
\text { "It's challenging to do if you do not have the talent. But after the challenges, } \\
\text { obstacles, and hindrances you face in making that sculpture you, will see the } \\
\text { beauty in it after you finish it." } \\
\text { "You should always prepare and be fully equipped to pass the challenges that you } \\
\text { will encounter, and help learners to learn and develop." }\end{array}$ \\
\hline $\begin{array}{l}\text { Pruning process, Flower, } \\
\text { Messy world }\end{array}$ & $\begin{array}{l}\text { Changes one's } \\
\text { perspective }\end{array}$ & $\begin{array}{l}\text { "You need to cut your undesirable traits. Even it is difficult to embrace change. It } \\
\text { is worth it." } \\
\text { "If you do not give importance to it, it will fail, the flower will not grow." } \\
\text { "But I've learned so much in my practice teaching days, and I learned how to } \\
\text { manage myself, how to control." }\end{array}$ \\
\hline
\end{tabular}

\subsection{Teaching internship as a chance to be a surrogate parent}

The teaching internship is also conceived to be a chance for the participants to become a surrogate parent as shown in Table 3. Since teachers are considered the second parents, the interns perceived that the internship program allows them to become parents to their learners. They mentioned being an instant parent, a surrogate parent and a role model as metaphoric representations, which implies that the practicum teaches them to love and respect children. Another notable object identified is a candle, which symbolizes enabling the learners' dreams. The use of dark chocolate and referee as representations implies the role of teaching internship in assisting the interns in their instructional routines.

Table 3. Prospective teachers' conceptions of teaching internship as a chance to be a surrogate parent

\begin{tabular}{|c|c|c|}
\hline Metaphoric representations & Associated meanings & Significant statements \\
\hline Dark chocolate, Referee & $\begin{array}{l}\text { Assists in instructional } \\
\text { routines }\end{array}$ & $\begin{array}{l}\text { "It's bittersweet because there are times that you will really feel so tired, } \\
\text { exhausted, and about to give up because of stress but it tastes so sweet when } \\
\text { you realize you have overcome the lesson planning, and creating } \\
\text { instructional materials." } \\
\text { "I serve as a referee in the classroom whenever I need to discipline the } \\
\text { children." }\end{array}$ \\
\hline
\end{tabular}

\subsection{Teaching internship as an enhancement of pedagogical competence}

Teaching internship was also metaphorically described as an enhancement of pedagogical competence as shown in Table 4. The PTs acknowledge that what they learned inside the classroom is not adequate, thus engaging in a practicum may further enhance their instructional strategies and pedagogical skills. The use of the metaphor, the friendly battle would mean equipping oneself to be a holistic person. Moreover, the use of metaphoric representations such as song, online games, a knife being sharpened, cooking, clock, battle and tuning a guitar represents the role of teaching internship in enhancing the prospective teachers' ability to teach. Employing effective classroom management also surfaced in the data with military training and doing a watercolor art as its corresponding metaphoric images. 
Table 4. Prospective teachers' conceptions of teaching internship as an enhancement of pedagogical competence

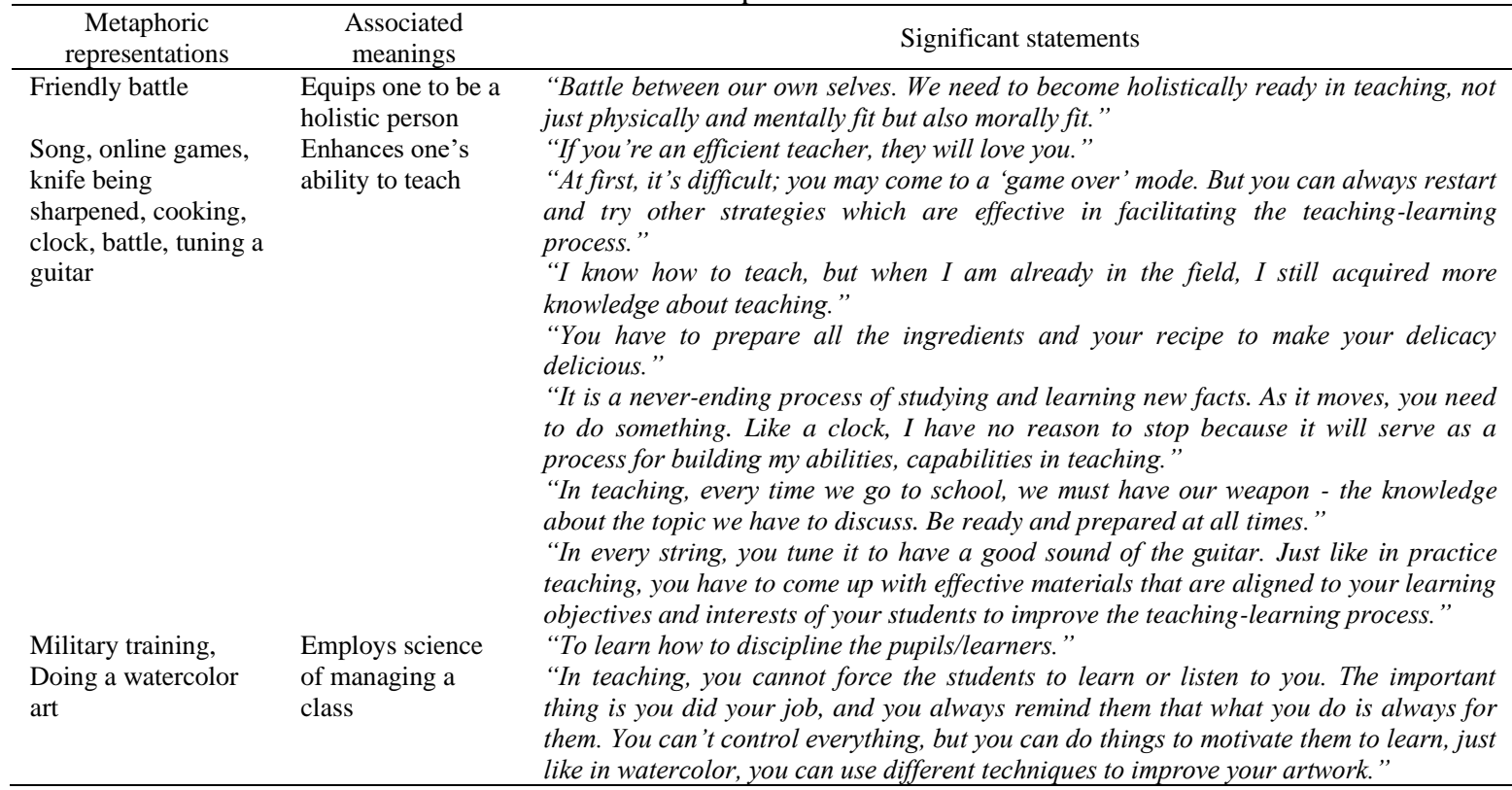

\subsection{Teaching internship as an immersion in the actual workplace}

The concept that internship is an immersion in the actual workplace is common knowledge as shown in Table 5. Interestingly, the prospective teachers made use of the battleground, managing one's family and an eye-opener as metaphorical representations of this conception. This connotes that teaching internship allows the PTs experience and see the reality of teaching primarily in the public school.

Table 5. Prospective teachers' conceptions of teaching internship as an immersion in the actual workplace

\begin{tabular}{lll}
\hline Metaphoric representations & Associated meanings & Significant statements \\
\hline Battleground, managing & Allows to experience & "To be in the practice teaching is a really great experience. I see how big \\
one's family, eye opener & and see the reality & the battleground is for the teacher. Yes, it has many papers works to do, but \\
& & the happiness of watching your students learn makes my heart happier." \\
& & "I realized that this is the reality being in a public institution; this is what it \\
& feels like."
\end{tabular}

\subsection{Teaching internship as an ultimate path towards becoming a teacher}

Teaching internship is likewise conceived as an ultimate path towards becoming a teacher as shown in Table 6. According to the participants' narratives in Table 6, the practicum helps them realize their personal goals to become a teacher. Walking in two different ways, mountain climbing, sailing in the sea, and the ladder were used as metaphorical images by the prospective teachers to depict that the practicum is the penultimate process before they complete the teacher education program. Figure 1 shows the crystalized conceptual framework showing the six categories of the metaphorical images that emerged in this study.

Table 6. Prospective teachers' conceptions of teaching internship as ultimate path towards becoming a teacher

\begin{tabular}{lll}
\hline Metaphoric representations & Associated meanings & Significant statements \\
\hline Walking in two different & Helps in the & "You're walking along with your dreams to become a teacher someday \\
ways, Mountain climbing, & realization of & but on the other hand, you're also going into your worst nightmare." \\
Sailing in the sea, Ladder & personal goals & "You will experience a lot of difficult things, but at the same time, you \\
& will find new things that will make you feel excited looking at the \\
future and feel happy while achieving your goals, to be on the top of & the mountain." \\
& "To be in the practice teaching is like a ladder. To pursue and \\
& continue your internship journey, you must take a step from your fears \\
& and take another step for the struggle you are about to face. Take \\
& another step to all the people who support you."
\end{tabular}




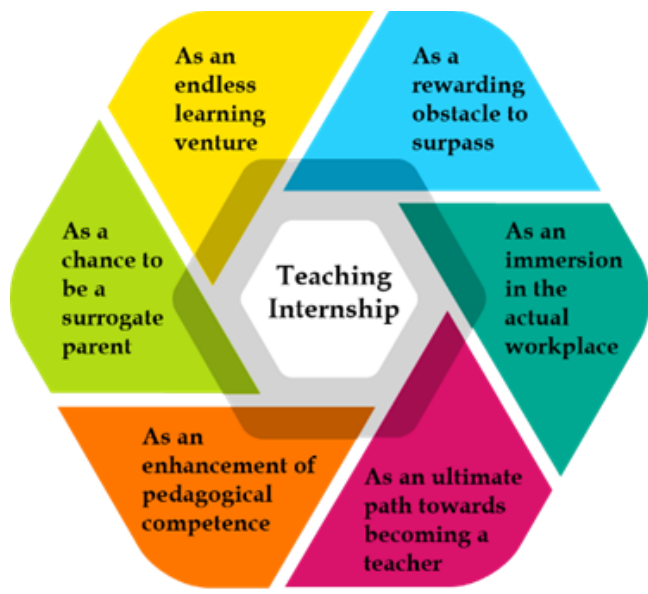

Figure 1. Conceptual framework of pre-service teachers' conception of teaching internship

This study explored the Filipino prospective teachers' (PTs) conceptions of teaching internship through a metaphorical lens. Filipino prospective teachers' conceptions revealed that the teaching internship is an endless learning venture, a rewarding obstacle to surpass, a chance to be a surrogate parent, an enhancement of pedagogical competence, an immersion in the actual workplace, and an ultimate path towards becoming a teacher. These conceptions, crystallized in a conceptual framework, may serve as a basis for further studies. The crystallized conceptual framework may also inform teacher education institutions (TEIs) on the prospective teachers' conceptions on teaching internship which can have important implications to a policy regarding the supervision of the teaching internship program.

The study found out that the PTs' personal schema of the process is heavily based on personal experiences and their learnings in their professional education courses. This study also saw that these conceptions are heavily affected by the completion of their off-campus teaching program.

The PTs viewed teaching internship as an endless learning venture. Thus, there is a need to prepare effective prospective teachers in the continuous learning process, whom Stronge, et al. [33] describe as chief catalysts for school development. They also viewed the internship program as a rewarding obstacle to surpass. They see the program as a preparation to deal with conflicts and problems that may also encounter in actual workplace. Managing these problems would prepare them for more significant conflicts that they need to settle as they become employed in the state education department. The internship journey is a significant aspect of a teacher education program [34] that plays an essential role in equipping the prospective teachers and defining their level of self-esteem [35] to deal with a myriad of problems and conflicts.

The prospective teachers also saw the teaching internship as a chance to be a surrogate parent. Since teachers are considered second parents of the learners in the school environment, the PTs also think themselves as second parents of the learners as they encounter the students every day in the classroom. The prospective teachers also feel the need to experience the magic of touch just like the parents to build a stronger relationship with their learners, leading to a higher level of learning both academically and nonacademically. They also viewed the internship as an enhancement of their pedagogical competence. Through the program, they believe that they will be able to apply the concepts, theories, and principles learned from their pre-service education to the actual classroom with real students and the real teaching-learning process. Through practicum teaching, PTs will be able to enhance their pedagogical knowledge (PK) as well as their content knowledge (CK) and technological knowledge (TK). Their PK has something to do with how knowledgeable they are in using various teaching strategies and approaches in their fields of discipline. Their CK has something to do with their knowledge about their subject matter that they need to deliver to their learners. While, the TK refers to their understanding of the use of relevant technologies in their teaching. These knowledge sets comprise their pedagogical competence that could be enhanced more through their internship program. Teaching internship is a gateway through which PTs become capable and can apply their content and pedagogical knowledge [36]. The internship experience is a vital phase that helps PTs to grow from being student teachers to full-fledged professionals [37] who develop professional and moral ethics and proficient skills in pedagogical strategies [38]. The prospective teachers' content knowledge and pedagogy may be further enhanced through their internship journey. The PTs could be guided by the cooperating teacher or critic teacher through checking their lesson plans, critiquing their instructional materials, and observing their actual classroom teaching. 
Immersion to the actual workplace is another conception of the PTs on teaching internship. The teaching practicum helps PTs bridge theory to practice and progress professionally through actual experiences [39]. It is critical for the teaching internship program to introduce the PTs to actual classroom instructional experiences that will allow them to realize the connection of theory to teaching and practice [40]. Lastly, the PTs saw practicum teaching as an ultimate path towards becoming a teacher. The internship program is the final course that PTs need to take in order to finish a degree in teaching. They can then apply for a licensure examination before teaching in private and public schools in the Philippines. It is critical that the students take their internship program seriously to be equipped with the necessary knowledge, skills, and values needed in the actual teaching workplace. Teaching practice is an essential share of teacher training [41]. Teaching is not only about being aware of the instructional theories and tenets but also about application and practice [42]. Practicum is required in earning a teacher education degree and before becoming a full-fledged educator [26]. Exposing the prospective teachers in the actual workplace could immerse them in the actual processes in the educational setting to include dealing with diverse learners, curriculum planning, assessing, and reporting, and other teaching responsibilities.

This paper provided some confirmation for the results of previous investigations. Internship is considered as a bridge to the real world of work as students have the chance to apply theoretical and practical knowledge obtained in a classroom to the actual work setting [43]-[46]. This paper's findings also corroborate in the previous studies that internship program also enhances the PTs' pedagogical competence and professional beliefs [47], [48]. The individual schema of prospective teachers is a product of their numerous encounters with their students, teachers, parents, and school administrators. The teaching internship concepts emerged from the metaphoric images culled out from the participants' responses exhibited rich experiences in their journey as student teachers. Moreover, the participants' difficulties and struggles entailed in the training process were viewed positively and see these challenges as driving forces to becoming better would-be teachers. The problems of handling big classes, shortage of instructional facilities, and even dealing with learners with diverse needs were also amplified in the student interns' responses. This suggests an explanation for the mixed responses of the participants using positive and negative metaphoric representations.

The contribution of this qualitative investigation to the existing knowledge is the additional definition of teaching internship based on the crystallized themes. Teaching internship is an ultimate path towards becoming a teacher and an endless learning venture where prospective teachers surpass rewarding obstacles as they assume the role of a surrogate parent in their immersion in the actual workplace while enhancing their pedagogical competence. Another contribution of the study is the use of metaphorical analysis in teacher education in the local context. The use of metaphors is very important to probe the conceptions, perspectives and experiences of any group of individuals, such as prospective teachers, to have a general picture of what they see, think, and feel.

\section{CONCLUSION}

This qualitative inquiry described the Filipino prospective teachers' (PT) conceptions of teaching internship. The Filipino PTs' viewed teaching internship as an endless learning venture, a rewarding obstacle to surpass, a chance to be a surrogate parent, an enhancement of pedagogical competence, an immersion in the actual workplace, and an ultimate path towards becoming a teacher. The perspectives culled from the study may serve as a basis for further studies. Further, these conceptions may serve as a clarion call to teacher education institutions (TEIs), specifically the teaching internship coordinators, to revisit the program and align this in the 21st-century learning landscape and for Education 4.0 as we face the volatile, uncertain, complex, ambiguous, disruptive and diverse $\left(V_{U C A D}^{2}\right)$ world. Since the COVID-19 pandemic aggravates the VUCAD ${ }^{2}$ world, TEIs may rethink and revisit the policies, standards, and guidelines of the conduct of the teaching internship in the post-COVID era. The students' actual or lived experiences may serve as a reference to better improve the teaching internship program in TEIs and produce more effective, globally competitive, and industry-ready teachers in the future. In this respect, TEIs need to review the policies and programs in relation to the student immersion as these manifests their metaphoric images of the program. The pre-service education students' various metaphoric representations on teaching internship may influence them as they engage in the teaching career after graduation.

This study only described the conceptions of the PTs on teaching internship qualitatively through written narratives. Further researchers may employ other approaches such as doodling or drawing to validate the present study's findings. This study's qualitative responses may likewise be used to develop a survey tool to describe PTs' views on teaching internship. Meanwhile, it is also recommended to include other year levels in exploring teacher education students' conceptions of the teaching internship. Another study may be done to describe their conceptions of the internship program before their immersion and during the 
COVID-19 educational disruption. A follow-up study may also be done to explore the influence of the teaching internship metaphoric images on the education graduates' actual teaching career.

\section{ACKNOWLEDGEMENTS}

The authors wish to express their profound gratitude to the President Ramon Magsaysay State University for the financial support for the publication of this research article. The researchers likewise acknowledge the Filipino prospective teachers for their willingness to be part of this qualitative inquiry.

\section{REFERENCES}

[1] J. Robertson, "(Re)creating a higher education community of inquiry," In HERDSA 2003 Conference Proceedings, 2003. [Online]. Available: https://www.herdsa.org.au/sites/default/files/HERDSANews20032501.pdf.

[2] M. Ben-Peretz, N. Mendelson, and F.W. Kron, "How teachers in different educational contexts view their roles," Teaching and Teacher Education, vol. 19, no. 2, pp. 277-290, 2003.

[3] L. Starkey and P. Rawlins, "Student teacher learning during practicum experience," Teacher Education Advancement Network Journal (TEAN), vol. 4, no. 1, pp.1-19, 2012.

[4] B. Genc and K. Buyukkarci, "An assessment of pre-service language teachers' practicum observation forms: descriptive observation vs. critical observation," Educational Research Ejournal, vol. 2, no. 2, pp. 83-91, 2013.

[5] A. Coskun, "Stress in English language teaching practicum: the views of all stakeholders," Hacettepe Üniversitesi Eğitim Fakültesi Dergisi, vol. 28, no. 28-3, pp. 97-110, 2013.

[6] E.C. Cheng, "Enhancing the quality of pre-service teachers' learning in teaching practicum," Education Sciences, vol. 1, pp. 6-16, 2013.

[7] Z. Gan, "Learning to teach English language in the practicum: What challenges do non-native ESL student teachers face?" Australian Journal of Teacher Education, vol. 38, no. 3, pp. 92-108, 2013.

[8] D. Hamaidi, I. Al-Shara, Y. Arouri, and F.A. Awwad, "Student-teachers' perspectives of practicum practices and challenges," European Scientific Journal, vol. 10, no. 13, 2014.

[9] B. A. Leke-ateh, T.E.B. Assan, and J. Debeila, "Teaching practice for the 21 st century: Challenges and prospects for teacher education in the North-West Province, South Africa," Journal of Social Sciences, vol. 37, no. 3, pp. 279-291, 2013.

[10] J. Bosnyak and N. Gancs, "The motivational disposition of English language teacher trainees," Working Papers in Language Pedagogy, vol. 6, pp. 64-78, 2012.

[11] Z. Jusoh, "Teaching practicum: Student teachers' perspectives," In FLT Conference Proceedings, 2013, pp. 885-874. [Online]. Available: http://www.litu.tu.ac.th/journal/FLLTCP/Proceeding/865.pdf.

[12] N. Yusof, A. Yusof, A.B.M. Ali, C.M. Yusoff, M.N. Farza, and N.B.M. Nawai, "Student teachers perception towards teaching practicum programme," International Journal of Innovation Education and Research, vol. 2, no. 10, pp. 121-130, 2014.

[13] H. Kadbey and M. Dickson, "Emirati pre-service teachers' experiences of teaching science during college internships," Education, Business and Society: Contemporary Middle Eastern Issues, vol. 7, no. 4, pp. 216-228, 2014.

[14] E.L.R. Abulon, "Preservice teachers' motivation related to career choice: The case of PNU BECED and BEED students," The Normal Lights, vol. 6, no. 1, pp. 68-79, 2012.

[15] E.L.R. Abulon and T.T. Rungduin, "A narrative analysis of conversations with graduates who did not pursue teaching: Inputs to teacher education policies in the Philippines," International Journal of Research Studies in Education, vol. 4, no. 2, pp. 13-27, 2015.

[16] E.L.R. Abulon and M. Balagtas, "A phenomenographic inquiry on the concept of competence among Filipino teachers," International Journal of Research Studies in Education, vol. 5, no. 3, pp. 91-104, 2016.

[17] E.L.R. Abulon, "Basic education teachers' concept of effective teaching: Inputs to teacher education curriculum in the Philippines," International Journal of Research Studies in Education, vol. 3, no. 3, pp. 35-48, 2014.

[18] M.A. Bustos-Orosa, "Inquiring into Filipino teachers' conceptions of good teaching: A qualitative research study," Asia-Pacific Education Researcher, vol. 17, no. 2, pp. 157-171, 2008.

[19] D.V. Rogayan Jr, "Why young Filipino teachers teach?" Asia Pacific Higher Education Research Journal, vol. 5, no. 2, pp. 48-60, 2018.

[20] L.P. Relon, "Internship away from home: A case study in a state university," Asia Pacific Journal of Multidisciplinary Research, vol. 8, no. 3, pp.18-29, 2020.

[21] M.B. Ulla, "Pre-service teacher training programs in the Philippines: The student-teachers practicum teaching experience," EFL Journal, vol. 1, no. 3, pp. 235-250, 2016.

[22] R. B. Mahinay, "Contextual performance of teacher education institutions (TEIs) in the Philippines," 2013. [Online]. Available: https://www.researchgate.net/publication/236622259_Contextual_Performance_of_Teacher_ Education_Institutions_TEIs_in_the_Philippines.

[23] M.G. Tangaro, M. G, "Student interns' feedback on student internship program in the Philippines: Basis for an enhanced internship program," International Journal of Advanced Research in Management and Social Sciences, vol. 8, no. 6, pp. 408-426, 2019.

[24] D.J. Tindowen, J. Bangi, and C. Parallag, "Pre-Service teachers' evaluation on their student internship program," International Journal of Learning, Teaching and Educational Research, vol. 18, no. 10, pp. 279-291, 2019. 
[25] N.V. Marasigan, "Predicting internship success of pre-service teachers," International Journal of Recent Innovations in Academic Research, vol. 2, no. 7, pp. 112-124, 2018.

[26] J. P. Erfe, et al., "The road to teaching," Asia Pacific Higher Education Research Journal, vol. 7, no. 1, pp. 1-14, 2020.

[27] C.D.L. Carillo, "Filipino pre-service education students' preconceptions of teacher roles viewed through a metaphorical lens" Asia-Pacific Journal of Teacher Education, vol. 35, no. 2, pp. 197-217, 2007.

[28] P. N. Valdez and J. Villorente-Saulo, "Math is like... because...: A metaphor analysis of Filipino students' perceptions of mathematical operations," Proceedings of the International Conference: DRAL, vol. 2, 2014, pp. 138-144.

[29] G. Lakoff and M. Johnson, Metaphors we live by. University of Chicago Press, 1990.

[30] M.A. Martinez, N. Sauleda, and G.L. Huber, "Metaphors as blueprints of thinking about teaching and learning," Teaching and Teacher Education, vol. 17, pp. 965-977, 2001.

[31] A. Saban, "A Turkish profile of prospective elementary school teachers and their views of teaching," Teaching and Teacher Education, vol. 19, pp. 829-846, 2003.

[32] D. Holt-Reynolds, "What does the teacher do? Constructivist pedagogies and prospective teachers' beliefs about the role of a teacher," Teaching and Teacher Education, vol. 16, pp. 21-32, 2000.

[33] J.H. Stronge, T.J. Ward, P.D. Tucker, and J.L. Hindman, "What is the relationship between teacher quality and student achievement? An exploratory study," Journal of Personal Evaluation in Education, vol. 20, no. 3/4, pp. $165-184,2007$.

[34] P. Grootenboer, "The impact of the school-based practicum on pre-service teachers' affective development in mathematics," Mathematics Teacher Education and Development, vol. 7, pp. 18-32, 2006.

[35] K. C. Goh, A. Wong, D. Choy, and J. Tan, "Confidence levels after practicum experiences of student teachers in Singapore: an exploratory study," Journal of Educational Policy, vol. 6, no. 2, pp. 121-140, 2009.

[36] J.M. Allen, and D. Peach, "Exploring connections between the in-field and on campus components of a pre-service teacher education program: a student perspective," Asia-Pacific Journal of Cooperative Education, vol. 8, no. 1, pp. 23-36, 2007.

[37] D. Allsopp, D. DeMarie, P. Alvarez-McHatton, and E. Doone, "Bridging the gap between theory and practice: connecting courses with field experiences," Teacher Education Quarterly, vol. 33, no. 1, pp. 19-35, 2006.

[38] J.H. Van-Driel, D. Beijaard, and N. Verloop, "Professional development and reform in science education: the role of teachers' practical knowledge," Journal of Research in Science Teaching, vol. 38, no. 2, pp. 137-158, 2001.

[39] I. Hussain, and S. Mahmood, "Practice teaching or internship: professional development of prospective teachers through their pre-service training programmes," Journal of Educational Research, vol. 13, no. 1, pp. 105-122, 2010.

[40] A.L. Hemmerich, J.K. Hoepner, and V.M. Samelson, "Instructional internships: Improving the teaching and learning experience for students, interns, and faculty," Journal of the Scholarship of Teaching and Learning, vol. 15 , no. 3, pp. 104-132, 2015.

[41] E.M. Kiggundu and S.T. Nayimuli, "Teaching practice: a make or break phase for student teachers," South African Journal of Education, vol. 29, no. 3, 2009.

[42] S. Rahmawati and F. Kurniawan, "Voicing the unvoiced Indonesian SEA teacher teaching in the Philippines: A phenomenological study," International Journal of Innovation, Creativity and Change, vol. 12, no. 6, pp. 45-55, 2020.

[43] N.F. Amin, A.A. Latif, M. Arsat, N. Suhairom, N.F. Jumaat, and M.E. Ismail, "The implementation of the internship as a coursework in teaching and learning vocational education," Journal of Technical Education and Training, vol. 12, no. 1, pp. 82-90, 2020.

[44] V.O. Rudio, R.D. Carreon, and E.S. Ocampo, "Student teachers' perceptions toward elementary education student teaching program in the Philippines," Universal Journal of Educational Research, vol. 8, no. 12, pp. 7036-7046, 2020.

[45] P. Silva, B. Lopes, M. Costa, D. Seabra, A.I. Melo, E. Brito, and G.P. Dias, "Stairway to employment? Internships in higher education," Higher Education, vol. 72, no. 6, pp. 703-721, 2016.

[46] H. Sumual and G.J. Soputan, "Entrepreneurship Education through Industrial Internship for Technical and Vocational Students," IOP Conference Series: Materials Science and Engineering, vol. 306, 2018.

[47] P. Mesker, H. Wassink, and C. Bakker, "How everyday classroom experiences in an international teaching internship raise student teachers' awareness of their subjective educational theories," Teacher Development, vol. 24, no. 2, pp. 204-222, 2020.

[48] T. Zulfikar, N. Nidawati, S. Khasinah, and I. Mayangsari, "Indonesian students' perceived benefits of the microteaching course to their teaching internship," Indonesian Journal of Applied Linguistics, vol. 10, no. 1, pp. 242-250, 2020. 